\title{
UDC 027.7:001.891
}

\section{KOSTYRKO T. M.}

Scientific Library, Admiral Makarov National University of Shipbuilding (Mykolaiv, Ukraine), e-mail: tamara.kostyrko@nuos.edu.ua, ORCID 0000-0002-4175-9975

KOROLOVA T. D.

Scientific Library, Admiral Makarov National University of Shipbuilding (Mykolaiv, Ukraine), e-mail: tetyana.korolova@ nuos.edu.ua, ORCID 0000-0001-8066-6141

\section{ANALYTICAL REVIEW OF ADMIRAL MAKAROV NUS'S PUBLICATION ACTIVITY IN INTERNATIONAL SCIENTOMETRIC PLATFORMS}

Objective. The article considers the analytical work of the Scientific Library of Admiral Makarov National University of Shipbuilding (NUS) on the publishing activity of the university at the international scientometric platforms. Methods of the research are based on a systematic approach, structural-functional and scientometric analysis of methods for evaluating the effectiveness and publication activity of academic staff and the university as a whole. Results. During the study, the authors proved: 1. Scientific Library of Admiral Makarov NUS actively implements innovative forms of activity, develops and diversifies the library service to aid the university research work; 2. The role of the Scientific Library as an active partner at the stages of the life cycle of scientific research of university scientists is growing; 3. Analytical work of the Scientific Library of Admiral Makarov NUS on the publishing activity of the university emphasizes and strengthens the role of the library in the processes of increasing the representation of university scientists in the global space of scientific communications, the introduction of scientometric and bibliometric research methods. Conclusions. Originality of the work lies in the expansion of ideas about the analytical work of the Scientific Library of Admiral Makarov NUS on the publishing activity of the university, which today is an important factor for further objective evaluation of the effectiveness of the academic library. This provides an opportunity to better understand the specifics of the scientific activities of HEI libraries as resource and information centres. Practical value. The obtained results can be used to increase the publishing activity of HEI at the international scientometric platforms.

Keywords: Admiral Makarov National University of Shipbuilding; library; publishing activity; scientometric indicators; scientometric analysis, bibliometric research, Scopus; Web of Science Core Collection

\section{Introduction}

One of the most important indicators of the significance and authority of the scientific activity of a modern higher education institution (HEI) is its publishing activity. It is the publishing process, being a factor in the accumulation of HEI's intellectual potential, that promotes the transfer of new knowledge to future specialists. Publication activity is a set of scientometric indicators used to assess the national scientific potential and compare it with the potential of other countries (Didenko \& Radchenko, 2017). Recently, publishing activity has become an important component of the overall strategy of HEI, which affects the amount of university funding and is one of the important components in compiling international rankings of universities, the result of comprehensive measures and efforts of HEI to enter the rating databases. As noted in (Tymofieieva \& Opryshko, 2020), publishing activity is part of an even greater task of developing the national scientific, technical and educational potential of a country that has embarked on the path of market development of education, which is being solved constantly and gradually. Therefore, the urgent task is to constantly monitor the current situation with university research and periodicals in order to obtain and analyse important statistical material that will allow to plan the development of domestic science. 


\section{Methods}

In most universities of Ukraine, the work with modern methods of monitoring and evaluating the research and technology growth, which primarily include bibliometrics, is already beginning to become part of a permanent and systematic activity - information analytics. And the units that take over the functions of publishing activity research are academic libraries (Korolova, 2018).

The strategy of the HEI library is seen in the direction of information-analytical monitoring and bibliometric analysis of the university's documentary communications system, creating preconditions for presenting scientists in international abstract databases and search engines (Scopus, Web of Science, Google Scholar, etc.), promoting the introduction of scientific periodicals into international databases, etc. (Nazarovets, 2016).

In October 2017, the Ministry of Education and Science of Ukraine began implementing a project to increase publication activity in the international scientific space of HEI scientists of Ukraine. For this purpose, the All-Ukrainian selection competition was held and more than $90 \mathrm{HEI}$ were provided with annual access to the leading scientometric platforms Scopus and Web of Science. Our university, as a participant in this project, gained access to the scientometric system Scopus. Scientific Library of the Admiral Makarov NUS not only coordinated this process, but also headed it. Today, the NUS library not only provides information and library support for the educational process and scientific activities, but also carries out research work, which is part of the multifaceted activities of the modern library of the HEI.

According to the order of NUS № 271 as of 14.11.2017 "On Increasing the Publication Activity of NUS", initiated by the Scientific Library, the university conducted a significant amount of work aimed at increasing the level of publication activity of scientists of our institution.

During 2017, two methodical manuals were prepared and published by NUS Publishing House: "Methodical Recommendations for Increasing the Publishing Activity of Graduate and Postgraduate Students" (authoring team of library specialists: T.M. Kostyrko, I.V. Bondar, M.S. Zhigalkina). The manual presents the criteria of publication activity of scientists and the quality of scientific publications, rules and algorithms for determining the main indicators of publication activity and citations, provides recommendations on how to prepare materials for publication in international periodicals, and lists the main scientometric databases; "Methodical Recommendations for the Use of Scientometric Platform Web of Science in Scientific Activities" (authors T.M. Kostyrko, I.V. Bondar).

To inform the academic staff of the university about the definition of UDC indices, scientometric indicators and databases, ratings of scientific journals, rules for bibliography, thesis requirements and much more the National Library of NUS during 2017-2018 formed an information block "For the Scientist" on its website. This block has pages "Scopus" and "Web of Science", which provide information about scientometric platforms, conditions for access to them, as well as a web navigator "Video Guide to Scientometric Databases", which is updated annually and supplemented with new materials. In 2020, the fourth issue of the web navigator has been prepared.

After gaining access, work with the Scopus and Web of Science scientometric platforms began with the integration of NUS organization identifiers and the creation of unified university profiles. Database administration is carried out throughout the access period (2017-2020): profiles of authors and institutions are regularly corrected, there is a search for authors and documents and possible matches of the university name. For better and more professional administration and 
detailed acquaintance with the possibilities of the database, the library staff actively participates in educational webinars.

Creating unified profiles of the institution in the databases Scopus and Web of Science Core Collection helps to determine the contribution of university science to the national and world scientific treasury, and with their help the staff of the Scientific Library regularly creates scientific and analytical materials, namely: indexes of journals and conference proceedings with published articles by scientists of the Admiral Makarov NUS, registered in the Scopus and Web of Science databases; author indexes of publications of NUS scientists in the Scopus and Web of Science databases; articles by scientists of Admiral Makarov NUS, published in journals and conference proceedings, registered in the Scopus and Web of Science databases. These materials are available on the website of the Scientific Library of NUS on the relevant pages.

The availability of scientific publications and the quality of periodicals are important criteria in determining the status of national and research universities.

In accordance with the provisions of the Law of Ukraine "On Higher Education" (Article 29), the status "national" is granted to the university in accordance with the procedure and criteria defined by the Cabinet of Ministers (Resolution of the Cabinet of Ministers No. 912 of November 22, 2017) "On Approval of the Procedure and Criteria for Granting National Status to Higher Education Institution, Confirmation or Deprivation of This Status"). According to this resolution, the HEIs must self-analyse the fulfilment of the criteria for granting and confirming the status of a national institution of higher education. According to the order of the Rector of NUS, the library staff is involved in self-analysis. They analyse the scientometric indicators of academic staff (AS) of NUS and provide a list of AS that have at least five scientific publications in periodicals, which at the time of publication were included in the scientometric databases Scopus and/or Web of Science.

For the second year in a row, the library staff carries out a scientometric analysis of NUS activities, which is used in the preparation of documents to ensure competitive selection of executors of state orders for training masters in HEIs, which are in the management of the Ministry of Education and Science (MES) in accordance with the MES Order No. 445 of May 5, 2018. To bring the scientific publications of the university in line with the requirements of the new List of scientific professional publications of Ukraine according to paragraph 6 of the MES Order No. 32 of 15.01.2018 in September 2018 NUS created a single editorial board comprising the director of the Scientific Library T.M. Kostyrko as the head of the bibliography and scientometrics sector. In order to comply with the requirements of international scientometric databases a package of documents were prepared for the editorial boards of periodicals, which includes: a list of authors of the university by the number of citations in the database Scopus and Web of Science; analysis of scientometric profiles of members of the editorial board of periodicals; scientometric indicators of members of the editorial board of periodicals of Admiral Makarov NUS.

One of the important conditions for reforming Ukrainian science is the need for state certification of HEI in terms of scientific activity, as provided by the Law of Ukraine "On Scientific and Scientific-Technical Activity". The procedure for conducting state certification of HEI was approved by the Resolution of the Cabinet of Ministers of Ukraine "Some Issues of Conducting State Certification of Higher Education Institutions in Terms of Their Academic (ScientificTechnical) Activities" (No. 652 of August 22, 2018). The Procedure states that the attestation assessment, as an individual characteristic of the achievements of a higher education institution in the scientific field, is calculated as the sum of the values of indicators (evaluated in points within the interval ranges of values) formed by certain components. The analysis of indicators of publishing activity of the university was used in its certification for effective academic and 
scientific-technical activities. Following the instructions of the Rector of NUS, the library staff analysed the publication activity of scientists for 2014-2018 (in 2019) and for 2015-2019 (in 2020) according to academic activity reports of all the departments and branches of the university, DB Scopus, Web of Science, Russian Science Citation Index. The analysis resulted in the tables "List of indicators for assessing the effectiveness of academic (scientific-technical) activities of higher education institutions in the scientific field and the potential for development of this scientific field" (P10-P13) and "List of scientific papers published during 5 year period in foreign publications that have an impact factor (separately DB Scopus, Web of Science)" in three areas: social sciences, engineering, mathematics and natural sciences.

The analysis revealed many shortcomings in the reports, so to fill out documents to assess the effectiveness of academic, scientific, technical and innovative activities used during the state certification, the Scientific Library proposed to develop a unified electronic form for annual academic activity reports of university departments and to include a list of 18 indicators for a combination of reliable quantitative and qualitative evaluation of statistical, scientometric data.

Recently, bibliometric indicators are increasingly considered as criteria for selecting individual researchers, HEI in general to receive financial assistance from donor organizations, government orders in the field of research activities of the institution and competitions. Twice a year, the Committee on State Prizes of Ukraine in Science and Technology awards grants of the Cabinet of Ministers of Ukraine for young scientists. Admiral Makarov NUS has repeatedly nominated university scholars for a grant. A prerequisite for obtaining a grant is an applicant's significant scientific results, so in 2020 it was decided that the Scientific Library staff would carefully check information about academic achievements provided by applicants from NUS and lists of their scientific publications over the past 5 years. Also, since 2020, the library staff has been involved in checking the publications of Ph.D. degree seekers, reviewers and opponents.

The increase in the HEI rating encourages a change in the principled approaches in the coverage of research results, because it is through publications that a research becomes known in the scientific community, paving the way for various grants. Therefore, it is very important to place scientific publications in internationally reputable periodicals that are part of scientometric databases. The Final Report of the Independent European Audit of the National Research and Innovation System of Ukraine states that the National Academy of Sciences of Ukraine (NASU) and universities should promote scientific publications in international journals and reduce departmental publications (Recommendation 12). The Horizon 2020 Policy Support Facility (PSF) panel recommends that universities and NASU encourage the use of English in publications and introduce an appropriate element in the evaluation criteria of individual scholars and institutes (Zakliuchnyi zvit..., 2017). Therefore, research institutions and universities should reduce the volume of internal publications, limited to those scientific journals that have a competitive effect. Preference should be given to journals that publish materials in English (Peer Review of Ukraine's research and innovation system, 2017). Therefore, during 2017-2020, the staff of the Scientific Library significantly increased the number of consultations to individual scientists and departments of the University on the search and selection of scientific periodicals, conferences, which are included in scientometric databases Scopus and/or Web of Science, for further publication.

Recently, the publishing activity of scientists has become one of the main factors taken into account in determining the ratings not only of individual professionals but also the ratings of departments and HEI in general, and publications become a real indicator of activity that leads to increased institution prestige. Therefore, in March-April 2018, the National Library of NUS took part in the Competition for the best academic paper on theoretical and applied aspects of 
comparative analysis of researchers, research teams and research institutions of Ukraine, which was announced by the Ministry of Education and Science of Ukraine; organizational and methodological support was provided by the State Scientific and Technical Library of Ukraine. According to the results of paper assessment by the Competition Commission, the research of the National Library of NUS was awarded the sixth place.

The competition work on the topic "Study of the Effectiveness of Scientific and ScientificMethodical Activities of the Admiral Makarov National University of Shipbuilding in Shipbuilding and Related Fields" presented the study of the dynamics of publishing activity and productivity of the university academic staff in the Scopus and Web of Science Core Collection DB for five years (2013-2017). The study covered: the dynamics of publication activity indicators in scientometric databases Scopus and Web of Science; distribution of publications by types of documents in the Scopus and WoS database of the NUS AS; the most influential journals in which the authors were published - AS of the Admiral Makarov NUS, according to the Scopus database in 2013-2017, by quartile; analysis of the publishing activity of the authors - AS of the Admiral Makarov NUS in the field of Engineering, etc.

As part of the competition, a sociological study was conducted on the attitude of NUS scientists to the scientometric databases Scopus and Web of Science. The competition work was prepared by: Director of the Scientific Library T.M. Kostyrko and the leading experts I.V. Bondar, T.D. Korolova, M.S. Zhigalkina.

The conducted research allowed to determine the priority directions of scientific developments, as well as the scientists - scientific leaders of the university. The results of the analysis of the publishing activity of the NUS AS were used as a tool to identify the weaknesses of the university's research activities and find ways to improve them.

Based on the study, an article "Scientific Activity Effectiveness of Admiral Makarov National University of Shipbuilding in the Field of Shipbuilding and Related Industries Research" was prepared, published in 2019 in the journal "Interdisciplinary Studies of Complex System" (indexed in the Web of Science database).

The staff of the library at different times prepared the following researches: "Scientometric Analysis of the Thesis Fund of the Scientific Library of NUS (2012, author T.M. Kostyrko), "Scientometric Analysis of the Thesis Fund of the Scientific Library of NUS to Improve the Publishing Activity of University Scientists" (2013, authors T.M. Kostyrko, I.V. Bondar), "Bibliometric Analysis of the Development of the Direction 'Dredging' in World Practice" (2019, authors T.M. Kostyrko, T.D. Korolova), "Bibliometric Evaluation of Research in the Field of 'Dredging' in Scopus Database" (2019, authors T.M. Kostyrko, T.D. Korolova), "Bibliometric Analysis of Scientific Publications which Include the Authors - AS of Admiral Makarov NUS (according to the scientometric database Scopus)" (2020, authors T.M. Kostyrko, T.D. Korolova), "Bibliometric Evaluation of Research in the Field of Nanostructuring of Industrial Metals and Alloys, Sprayed Coatings in Scopus Database)" (2020, authors T.M. Kostyrko, M.S. Zhigalkina).

In 2020, by order of the Vice-Rector for Research of the Admiral Makarov NUS the following was carried out: "Monitoring the Publication Activity of $\mathrm{PhD}$, Doctor and Candidate of Sciences Degree Seekers" in the DB of Scopus, Web of Science and Google Scholar (the monitoring covered the publication activity of four Doctor degree seekers and 70 Candidate of Sciences degree seekers, PhD of all structural units); "Authors of the Admiral Makarov NUS Leaders in the Scopus for 2015-2020 (not less than 5 publications for 2015-2020, or not less than 10 publications for 2010-2020 in periodicals of the first (Q1) and second (Q2) quartiles according to the Scimago classification)"; "Authors of the Admiral Makarov NUS - Leaders in the Web of Science for 2015-2020 (not less than 5 publications for 2015-2020, or not less than 10 publications 
for 2010-2020 in periodicals of the first (Q1) and second (Q2) quartiles according to the Journal Citation Reports classification)"; "Authors of the Admiral Makarov NUS - Leaders in the Scopus for 2019 (publications in periodicals of the first (Q1) and second (Q2) quartiles according to the Scimago classification)"; Authors of the Admiral Makarov NUS - Leaders in the Web of Science for 2019 (publications in periodicals of the first (Q1) and second (Q2) quartiles according to the Journal Citation Reports classification)".

Analysing the publishing activity of scientists and the university in general, the library staff emphasizes the need to enhance research productivity by increasing the number of articles in highquality rated scientific journals. Scientists need to take care of their dissemination and citation, so that they could receive as wide readership as possible. This is possible if they are published in leading journals with a high impact factor, while promoting domestic journals in their field by citing publications (their own and those of other researchers) from them. Faster citation will be facilitated by the placement of articles in open access journals, as well as the presence of the author's profile in special scientific social networks (ResearsherGate, Mendeley, etc.).

In addition to the analysis of publishing activities, today the work of the library is aimed at teaching and extensive acquaintance of researchers and students of the university with the peculiarities of the promotion and monitoring of scientific publications in international scientometric databases. For this purpose, the library specialists have developed and regularly conduct various informational and educational activities for academic staff and students of higher education to increase publication activity and citation index of NUS authors on the topics: "Scientometric databases. Citation index and teachers' tasks"; "International e-resources to help the author"; "Increasing the index of citation of own works"; "How to write an article for an international journal"; "Basic principles of NUS electronic repository", "Academic integrity", "What is plagiarism and how to avoid it?", "Presentation of research results", "Electronic resources for science and education", "Science in Open Access". Individual and group consultations on information culture, academic integrity and academic culture are regularly provided: "New thesis requirements", "International styles of scientific publications", "Ukrainian alphabet transliteration", "How to avoid ethical violations in science", "Ukrainian journals in Scopus and Web of Science", "Creating a scientometric profile of a scientist", "Features of scientific declaration" and many others.

For the scientific community of the university, librarians of the leading universities of Mykolaiv with the assistance of our library held the scientific and methodical seminars and trainings: on the Web of Science platform possibilities for qualitative scientific researches (Web of Science Core Collection, Journal Citation Report, EndNote, ResearcherID), Speaker Iryna Tikhonkova, Candidate of Science in Biology, Clarivate Analytics Learning and Analytical expert (2017 and 2019); on work with the Scopus database, speaker Serhiy Nazarovets, Candidate of Sciences in Social Communications, Deputy Director of the State Scientific and Technical Library of Ukraine, Elsevier trainer (2019); on the formation of the student's academic culture and the possibilities of the Unicheck service, Speaker Andrii Sidliarenko, Director of the Anti-Plagiarism Ltd. (2019).

The Scientific Library of Admiral Makarov NUS, restructuring its own activities for the maximum development of services to support scientific publications, provides assistance in integrating publications into world databases, develops services to support scientific publications, on a regular basis provides assistance in integrating scientific publications in world databases, advises and assists in creating profiles in Google Scholar, information-analytical system "Bibliometrics of Ukrainian Science", author IDs ORCID and Researcher ID (Publons). 


\section{Results}

Managing publishing activity is a rather complex, multifactorial task. To increase publishing activity, a systematic approach is important, which will take into account various aspects, and the result can be achieved based on the cumulative systemic effect. The joint activities of the library, scholars, departments and administration to increase the publishing activity of the university strengthens the communication links between the library and departments, expands the range of scholars who apply to the library, promotes the authority of the library as a professional expert community. It forms new demanded functions in the modern academic library and restores its most important social function - the promotion of science and education.

Therefore, the Scientific Library of Admiral Makarov NUS actively implements innovative forms of activity, develops and diversifies the library service to aid the university research work. The role of the Scientific Library as an active partner at the stages of the life cycle of scientific research of university scientists is growing. Analytical work of the Scientific Library of Admiral Makarov NUS on the publishing activity of the university emphasizes and strengthens the role of the library in the processes of increasing the representation of university scientists in the global space of scientific communications, the introduction of scientometric and bibliometric research methods.

\section{Conclusions}

The potential of scientific activity of libraries is inherent in its functions and requires by its nature the need to constantly meet the needs of scientific knowledge and socio-cultural development of society (Dubrovina, 2019), while innovative changes in the content, forms and methods of library activities influence the improvement of the scientific activity of the educational institution, bring noticeable socially significant results, increase the rating of the university. The library, as a modern scientific and information centre of the HEI, defines the strategy for the development of a new communication environment: changes the orientation of activities in the media environment to create a content strategy; positions itself as a reliable and secure source of information, using all products and services, takes advantage of the technologies of social media marketing, exchange, self-organization, etc. (Bilous, 2017).

Today, bibliometric and scientometric research, monitoring of the university in the world information space, promotion of open access to research results of university scientists, constant coverage of information-analytical monitoring of authors' publication activity on university websites, libraries, social networks forms a model of a modern HEI's library. The organization and conduct of bibliometric research logically expand the professional activities of university libraries; increase their status in the scientific community; increase the degree of involvement in the processes of research and university management; consolidate the influence and prestige of the library within the university. As a result, the professional roles and tasks of information and library professionals are being rethought, new competencies are being developed and formed, and, accordingly, new library services are emerging (Kostyrko, 2018).

The Scientific Library of Admiral Makarov NUS, as an information-analytical centre of the university, takes an active position in creating a common interactive information environment, the centre of educational, scientific and social life of the university and offers a range of new library services and products, being a reliable partner of the university researcher, contributes to the growth of publishing activity of scientists, increasing their citation in international scientometric databases and strengthening university science at the national and world levels. 


\section{REFERENCES}

Bilous, V. (2017). Vykorystannia metrychnykh metodiv doslidzhennia u bibliotetsi vinnytskoho Derzhavnoho pedahohichnoho universytetu imeni Mykhaila Kotsiubynskoho. Odesa National University herald. Series: Library studies, bibliography studies, bibliology, 22(2), 225-241. doi: http://dx.doi.org/10.18524/2304-1447.2017.2(18).118296 (in Ukranian)

Didenko,Yu. \& Radchenko, A. (2017). Publikatsiina aktyvnist yak sposib naukovoi komunikatsii ta honytvy za reitynhamy. Visnyk NAN Ukrainy, 9, 82-98. doi: https://doi.org/10.15407/visn2017.09.082 (in Ukrainian)

Dubrovina, L. (2019). Natsionalni biblioteky Natsionalnoi akademii nauk Ukrainy v protsesi atestatsii naukovykh ustanov: aspekt otsiniuvannia publikatsiinoi aktyvnosti. National Academy of Managerial Staff of Culture and Arts Herald, 2, 69-73. doi: https://doi.org/10.32461/22263209.2.2019.175481 (in Ukranian)

Korolova, T. (2018). Analitychnyi ohliad publikatsiinoi aktyvnosti naukovtsiv Natsionalnoho universytetu korablebuduvannia imeni admirala Makarova $\mathrm{v}$ mizhnarodnykh naukometrychnykh informatsiinykh resursakh. $V$ Vseukrainska naukovo-praktychna konferentsiia za temoiu «Naukovo-komunikatsiinyi prostir biblioteky ZVO: vymohy chasu ta realii», 1-2 lystopada 2018, Mykolaiv. Retrieved from https://cutt.ly/Rf6iWx2 (in Ukranian)

Kostyrko, T. (2018). Dosvid roboty naukovoi biblioteky z pidvyshchennia publikatsiinoi aktyvnosti ta rezultatyvnosti naukovo-pedahohichnykh pratsivnykiv NUK imeni admirala Makarova. III mizhnarodna naukovo-praktychna konferentsiia «Biblioteky zakladiv vyshchoi osvity: dosvid ta perspektyvy», 4-6 lypnia 2018, Odesa. Retrieved from http://liber.onu.edu.ua/konf2018/11.pdf (in Ukranian)

Nazarovets, M. (2016). Sluzhba informatsiinoho monitorynhu yak strukturnyi pidrozdil suchasnoi akademichnoi biblioteky. Visnyk Knyzhkovoi palaty, 8, 24-26. Retrieved from http://irbisnbuv.gov.ua/cgi-

bin/irbis_nbuv/cgiirbis_64.exe?C21COM=2\&I21DBN=UJRN\&P21DBN=UJRN\&IMAGE_FILE DOWNLOAD=1\&Image file name $=P D F / v k p ~ 2016 \quad 8 \quad 6 . p d f$ (in Ukranian)

Tymofieieva, H., \& Opryshko, T. (2020). Ukrainski universytety v reitynhakh publikatsiinoi aktyvnosti 2019 roku. Open educational e-environment of the modern University, 8, 174-190. doi: https://doi.org/10.28925/2414-0325.2020.8.16 (in Ukranian)

Zakliuchnyi zvit nezalezhnoho yevropeiskoho audytu natsionalnoi systemy doslidzhen ta innovatsii Ukrainy (2017). HORIZON 2020. National portal. Retrieved from http://h2020.com.ua/wpcontent/uploads/2017/03/KI-AX-16-008-UK-N-Transl.pdf (in Ukranian) 


\section{КОСТИРКО Т. М.}

Наукова бібліотека, Національний університет кораблебудування імені адмірала Макарова (Миколаїв, Україна), e-mail: tamara.kostyrko@ nuos.edu.ua, ORCID 0000-0002-4175-9975 КОРОЛЬОВА Т. Д.

Наукова бібліотека, Національний університет кораблебудування імені адмірала Макарова (Миколаїв, Україна), e-mail: tetyana.korolova@ nuos.edu.ua, ORCID 0000-0001-8066-6141

\section{АНАЛТТИЧНИЙ ОГЛЯД ПУБЛІКАЦІЙНОЇ АКТИВНОСТІ НУК ІМЕНІ АДМІРАЛА МАКАРОВА В МІЖНАРОДНИХ НАУКОМЕТРИЧНИХ ПЛАТФОРМАХ}

Мета. У статті розглянута аналітична діяльність Наукової бібліотеки НУК ім. адм. Макарова 3 публікаційної активності університету в міжнародних наукометричних платформах. Методика дослідження базується на системному підході, структурно-функціональному та наукометричному аналізі методики оцінювання результативності та публікаційної активності науково-педагогічних, наукових працівників i університету в цілому. Результати. Під час дослідження авторами доведено: 1. Наукова бібліотека НУК ім. адм. Макарова активно впроваджує у свою діяльність інноваційні форми діяльності, розвиває та урізноманітнює бібліотечний сервіс на допомогу науково-дослідній роботі університету; 2. Зростає роль Наукової бібліотеки як активного партнера на стадіях життєвого циклу наукових досліджень науковців університету; 3. Аналітична діяльність Наукової бібліотеки НУК ім. адм. Макарова з публікаційної активності університету підкреслює та зміцнює роль бібліотеки у процесах збільшення представництва вчених університету в глобальному просторі наукових комунікацій, впровадженні наукометричних та бібліометричних методів дослідження. Висновки. Наукова новизна роботи полягає в розширенні уявлень про аналітичну діяльність Наукової бібліотеки НУК ім. адм. Макарова з публікаційної активності університету, що сьогодні є важливим чинником для подальшого об'єктивного оцінювання результативності академічної бібліотеки. Це надає можливість глибше усвідомити специфіку наукової діяльності бібліотек ЗВО як ресурсних та інформаційних центрів. Практична значимість. Отримані результати можна використовувати для підвищення публікаційної активності ЗВО в міжнародних наукометричних платформах.

Ключові слова: Національний університет кораблебудування імені адмірала Макарова; бібліотека; публікаційна активність; наукометричні показники; наукометричний аналіз; бібліометричне дослідження; Scopus; Web of Science Core Collection 